\title{
RealisticMathematicEducation pada Barisan dan Deret Aritmetika Berbasis Kehidupan Islami Pondok Pesantren
}

\author{
Ukhti Raudhatul Jannah $^{\left.1^{*}\right)}$, Towafi ${ }^{2}$
}

${ }^{1}$ Universitas Madura, ${ }^{2}$ Universitas Madura

\section{INFO ARTICLES}

\section{ArticleHistory:}

Received: 04-11-2019

Revised: 05-11-2019

Approved: 05-11-2019

Publish Online: 09-04-2020

\section{KeyWords:}

Pembelajaran Matematika, RealisticMathematicsEducation, Barisan dan Deret Aritmatika

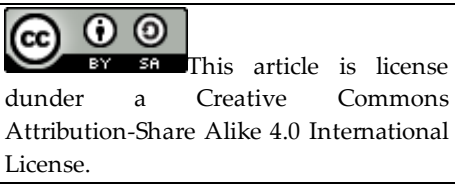

CorrespondenceAddress: Jln. mail:ukhti_math@unira.ac.id

HowtoCite (APA 6 $^{\text {th }}$ Style): Jannah, U.R.,\& Towafi (2020). ArticleTitle. JKPM (Jurnal Kajian Pendidikan Matematika), Vol 5 (1): 165-174.

Copyright:Jannah, U.R.,\& Towafi, (2020)

CompetingInterestsDisclosures: The authorsdeclarethattheyhavenosignificantcompetingfinancial, professionalor personal intereststhatmighthaveinfluencedtheperformanceorpresentationoftheworkdescribed in thismanuscript.

\begin{abstract}
The purpose of this research is to describe the Realistic Mathematics Education (RME) model in arithmetic sequence and series subject with basic of Islamic life in boarding school carried out during two meetings. This research is a descriptive qualitative study with the research subject was students of class XI IPA MA Matsaratul Huda. The results of the analysis of the observation data of the teacher's activities obtained the final value 3,805 and the results of the analysis of the observation data of the students' activities got the final score3,34. In addition, students also respond "positively" to learning by $98,5 \%$. Classically the results of student learning tests results $93,1 \% \geq 85 \%$ so that students' mastery learning can be said to be "completed". Based on the results of these studies it can be said that learning mathematics through Realistic Mathematics Education (RME) can help students to understand the material and can provide new knowledge about the relationshipof mathematics and Islamic life in boarding school.
\end{abstract}

\begin{abstract}
Abstrak:Penelitian ini bertujuan untuk mendeskripsikan model RealisticMathematicEducationpada materi barisan dan deret aritmetika berbasis kehidupan Islami Pondok Pesantren yang dilakukan selama dua kali pertemuan. Penelitian ini merupakan penelitian kualitatif deskriptif dengan subjek penelitiannya adalah siswa kelas XI IPA MA Matsaratul Huda. Hasil analisis data observasi aktivitas guru memperoleh nilai akhir 3,805 dan hasil analisis data observasi aktivitas siswa memperoleh nilai akhir 3,34. Selain itu, siswa juga merespon "Positif" terhadap pembelajaran dengan persentase 98,5\%. Secara klasikal hasil tes belajar siswa memeroleh hasil 93,1\% $\geq$ 85\% sehingga ketuntasan belajar siswa dapat dikatakan "Tuntas". Berdasar pada hasil penelitian tersebut dapat dikatakan bahwa pembelajaran matematika melalui RealisticMathematicEducation dapat membantu siswa memahami materi dan dapat memberikan pengetahuan baru tentang hubungan matematika dan kehidupan nyata yang berbasis Islami di lingkungan Pondok Pesantren.
\end{abstract}

Raya Panglegur Km 3,5 Pamekasan, Pamekasan, 69371, Indonesia; e- 


\section{PENDAHULUAN}

Matematika merupakan salah satu disiplin ilmu pengetahuan yang bisa digunakan sebagai pendekatan dalam menjelaskan beberapa doktrin dalam ajaran Islam (La Jamaa, 2015). Hal ini menunjukkan bahwa ada hubungan antara matematika dengan ajaran Islam sehingga pembelajaran matematika bisa menggunakan kehidupan Islami, baik dalam penggunaan masalah ataupun penerapan konsep matematika yang terdapat dalam kehidupan Islami tersebut. Misalnya ibadah shalat witir. Pada praktiknya, shalat witir yang berjumlah sebelas rakaat bisa dilaksanakan secara bertahap dalam hitungan ganjil, artinya bisa dilaksanakan satu rakaat, tiga, lima, tujuh, sembilan, dan sebelas rakaat. Konsep yang terkandung dalam contoh kehidupan Islami tersebut adalah konsep barisan aritmetika. Selain itu, ada beberapa kehidupan Islami yang bisa digunakan dalam pembelajaran matematika sehingga dapat memberikan inovasi baru bagi guru matematika untuk meningkatkan aktivitas belajar siswa terutama siswa yang berdomisili di Pondok Pesantren karena sebagian besar siswa yang berdomisili di Pondok Pesantren kurang berminat untuk mempelajari matematika. Mereka berpendapat bahwa ilmu agama lebih penting daripada matematika dan mereka juga berpendapat bahwa mereka tidak memiliki waktu untuk belajar matematika di luar jam sekolah. Oleh karena itu, penggunaan kehidupan Islami yang terdapat di pondok pesantren dalam pembelajaran matematika sangat penting untuk memotivasi siswa dalam mempelajari matematika.

Objek kajian matematika yang bersifat abstrak menjadi satu di antara penyebab kesulitan siswa dalam mempelajari matematika (Fathani, 2014). Sehingga Guru perlu menerapkan modelmodel pembelajaran matematika yang mengaitkan antara pemahaman konsep yang sudah dipelajari dengan pengalaman kehidupan nyata siswa tentang pembelajaran matematika. Guru dapat menggunakan kehidupan Islami yang biasa dilakukan oleh siswa di pondok pesantren sehingga mereka lebih mudah untuk memahaminya karena konsep matematika yang disajikan dalam bentuk konkret akan dipahami dengan baik oleh siswa (Jannah, 2013). Oleh karena itu, diperlukan suatu model pembelajaran yang dapat menghubungkan matematika dengan kehidupan nyata. Salah satu model pembelajaran matematika yang dikembangkan berdasarkan konteks nyata adalah Pendidikan Matematika Realistrik (PMR) atau RealisticMathematicEducation (RME) yang dikembangkan oleh Freudenthal di Belanda.

RealisticMathematicEducation (RME) merupakan pembelajaran matematika yang mengaitkan konsep matematika dengan pengalaman sehari-hari dan menerapkan matematika dalam kehidupan nyata. Freudenthal menyatakan bahwa matematika merupakan suatu bentuk aktivitas manusia (human activities) (Wijaya, 2012). Artinya matematika sebaiknya diberikan kepada siswa bukan sebagai suatu produk jadi yang siap pakai, melainkan sebagai suatu bentuk kegiatan dalam mengontruksi konsep matematika. Selain itu, RME merupakan salah satu pendekatan pembelajaran matematika yang menyenangkan dan relevan dengan kehidupan sehari-hari (Zulkardi, 2019). Hal ini disebabkan karena RME mengaitkan dan melibatkan lingkungan sekitar siswa dan pengalaman nyata yang dialami siswa dalam kehidupan sehari-hari serta menjadikan matematika sebagai aktivitas siswa (Subaidi, 2016). Oleh karena itu, model RME ini sangat cocok diterapkan dalam pembelajaran matematika dengan menggunakan kehidupan Islami yang biasa dilakukan oleh siswa di Pondok Pesantren karena pembelajaran menjadi menyenangkan dengan memberikan ilustrasi-ilustrasi berupa kehidupan nyata berbasis Islami di lingkungan Pondok Pesantren sehingga dapat memotivasi siswa dalam belajar matematika.

RME memiliki prinsip-prinsip yang didasarkan pada gagasan membangun pengetahuan oleh siswa itu sendiri, dan mayoritas peneliti berpendapat bahwa RME ini sangat bermanfaat untuk pembelajaran matematika (Papadakis, 2017). RME mencoba untuk melampaui dikotomi antara pengetahuan informal dan formal dengan merancang lintasan pembelajaran hipotesis, dimana siswa dapat menemukan kembali matematika formal sehingga matematika tersebut 
muncul dalam aktivitas matematika siswa (Gravemeijer, 1999). Hal ini yang membedakan RME dengan model pembelajaran yang lainnya. Selain itu, model RME tidak diberikan model siap pakai kepada siswa yang mewujudkan konsep matematika tertentu, tetapi mereka dihadapkan dengan masalah kontekstual dan disajikan sedemikian rupa sehingga mereka memperoleh pemodelan kegiatan dan menyebabkan munculnya sebuah model (Van Den Heuvel, 2003). Masalah kontekstual yang digunakan berupa kehidupan nyata yang biasa dialami oleh siswa. Dalam penelitian ini, peneliti menggunakan kehidupan Islami yang biasa dilakukan oleh siswa di dalam Pondok Pesantren. Artinya, peneliti menggunakan kegiatan-kegiatan yang berbasis Islami, seperti shalat berjamaah, ibadah shalat witir, ibadah shalatdhuha, kegiatan muhadharah, dan lain sebagainya.

MA Matsratul Huda merupakan lembaga pendidikan yang berada dibawah naungan Yayasan Pondok Pesantren sehingga subjek penelitian yang akan diteliti sangat relevan dengan tujuan penelitian. Sebagian besar siswa yang sekolah di MA Matsaratul Huda bertempat tinggal di Pondok Pesantren (santri). Mereka dituntut untuk disiplin waktu dengan mengikuti kegiatan pondok pesantren yang sebagian besar berupa kegiatan Islami. Berdasar pada hasil wawancara dengan beberapa siswa MA Matsaratul Huda mengatakan bahwa pelajaran matematika bukanlah ilmu agama sehingga mereka menganggap bahwa mempelajari matematika tidak ada manfaatnya dan tidak ada hubungannya dengan ajaran Islam. Bahkan mereka tidak memiliki waktu untuk belajar matematika karena kegiatan pondok pesantren yang sangat padat dengan kegiatankegiatan keagamaan. Hal tersebut mengakibatkan minat belajar siswa rendah dalam pelajaran umum terutama matematika. Di samping itu, pelajaran matematika yang dianggap sulit untuk dipelajari, salah satunya adalah materi barisan dan deret aritmetika. Pada materi tersebut siswa kurang mampu dalam memahami masalah sehingga mereka sulit untuk menganalogikan rumus dan angka. Hal ini dapat menyebabkan rendahnya hasil belajar siswa.

Materi barisan dan deret aritmetika dengan menggunakan model RealisticMathematicEducation(RME) dapat diaplikasikan dalam kehidupan nyata yang berbasis kehidupan Islami pondok pesantren. Pembelajaran tidak hanya mengajarkan terhadap pemahaman konsep saja, tetapi jugadiharapkan dapat menanamkan pengetahuan baru dalam diri siswa sehingga dapat membentuk siswa yang pintar, benar, dan profesional serta menyadari kemanfaatan matematika dalam kehidupan Islami. Tujuan penelitian ini adalah untuk mendeskripsikan model RealisticMathematicEducation (RME) pada materi barisan dan deret aritmetika berbasis kehidupan pondok pesantren di kelas XI MA Matsaratul Huda Panempan Pamekasan.

\section{METODE}

Penelitian ini menggunakan penelitian kualitatif deskriptif. Penelitian deskriptif adalah suatu bentuk penelitian yang paling dasar yang ditujukan untuk mendeskripsikan atau menggambarkan fenomena-fenomena yang ada, baik fenomena yang bersifat alamiah ataupun rekayasa manusia (Creswell, 2013). Penelitian dimaksudkan untuk mendeskripsikan pembelajaran matematika yang diterapkan pada subjek penelitian dengan menggunakan model RealisticMathematicEducation(RME) pada materi barisan dan deret aritmetika berbasis kehidupan Islami Pondok Pesantren.

Penelitian ini dilaksanakan di MA Matsaratul Huda Panempan Pamekasan dengan subjek penelitiannya adalah kelas XI IPA dengan jumlah siswa 29 orang yang terdiri dari 24 siswi dan 5 siswa. Penelitian ini dilaksanakan pada bulan April 2019 sampai dengan Juli 2019 tahun ajaran 2018/2019. Dalam hal ini peneliti sebagai keyinstrument (Moleong, 2013). Peneliti sendiri berperan sebagai guru (pelaku tindakan) dengan bantuan dua observer. Observer pertama yaitu guru matematika yang bertugas mengamati aktivitas guru (peneliti). Observer kedua yaitu teman sejawat yang bertugas mengamati aktivitas siswa selama proses pembelajaran berlangsung. Penelitian ini dilakukan dalam dua kali pertemuan. 
Teknik pengumpulan data dalam penelitian ini menggunakan dokumentasi, observasi, angket, dan tes. Peneliti menggunakan observasi sistematis untuk mengetahui aktivitas siswa dan guru.Observasi yang dilakukan oleh pengamat dengan menggunakan pedoman sebagai instrumen pengamatan. Peneliti juga menggunakan angket untuk mengetahui respon siswa terhadap proses pembelajaran. Selain itu, peneliti menggunakan tes untuk mengetahui ketuntasan hasil belajar siswa. Tes yang digunakan merupakan tes uraian yang terdiri dari empat soal. Tes tersebut berupa masalah-masalah kontekstual yang berhubungan dengan kehidupan sehari-hari. Tes ini diberikan setelah pembelajaran dilakukan.

Data yang telah dikumpulkan kemudian dianalisis. Adapun teknik analisis data hasil observasi guru dan siswa menggunakan analisis deskriptif dengan kriterian penilaian: Sangat Baik (A) dengan bobot 4, Baik (B) dengan bobot 3, Cukup (C) dengan bobot 2, dan Kurang (D) dengan bobot 1 . Nilai akhir observasi secara keseluruhan dapat dihitung dengan menggunakan rumus: $N A=\frac{\sum n}{\sum a}$. Dengan $\mathrm{NA}=$ nilai akhir, $\mathrm{n}=$ nilai setiap aspek yang diamati, dan $\mathrm{a}=$ aspek yang diamati. Sedangkan kategori penentuannya adalah: $0,00-1,49=$ tidak baik, 1,50 - 2,49= kurang baik, 2,50 - 3,49 = baik, 3,50 - 4,00 = sangat baik (Arikunto, 2016). Data angket respon siswa dianalisis dengan menggunakan rumus: $R_{i}=\frac{s_{i}}{n} \times 100 \%$, dengan $R_{i}=$ presentase siswa yang menjawab "YA", $S_{i}=$ banyak siswa yang menjawab "TIDAK", dan $n=$ jumlah siswa (responden). Respon siswa terhadap pembelajaran dianggap positif jika persentase rata-rata jawaban siswa yang menjawab "YA" $\geq 60 \%$, sedangkan respon siswa dianggap negatif jika persentase rata-rata jawaban siswa yang menjawab "YA" $<60 \%$. Sedangkan teknik analisis data hasil belajar siswa menggunakan ketuntasan secara individu dan klasikal. Siswa dapat dikatakan mencapai ketuntasan secara individu apabila hasil tes yang diperoleh mencapai kriteria ketuntasan minimal (KKM) yaitu 70. Ketuntasan belajar klasikal bisa tercapai apabila persentase Ketuntasan Belajar Klasikal (KBK) mencapai persentase $\geq 85 \%$ dari jumlah siswa dengan rumus $K B K=\frac{\text { jumlah siswa yang tuntas }}{\text { jumlah seluruh siswa }} \times 100 \%$.

\section{HASIL}

Setelah peneliti melakukan penelitian dengan menerapkan model RealisticMathematicEducation(RME) pada materi barisan dan deret artimetika yang berbasis kehidupan Islami pondok pesantren di kelas XI IPA Matsaratul Huda Panempan Pamekasan yang dilakukan selama dua kali pertemuan diperoleh hasil sebagai berikut:

\section{a. Aktivitas Guru dalam Pembelajaran}

Observasi terhadap aktivitas guru dilakukan selama proses pembelajaran selama dua kali pertemuan. Berikut ini dokumentasi aktivitas guru:
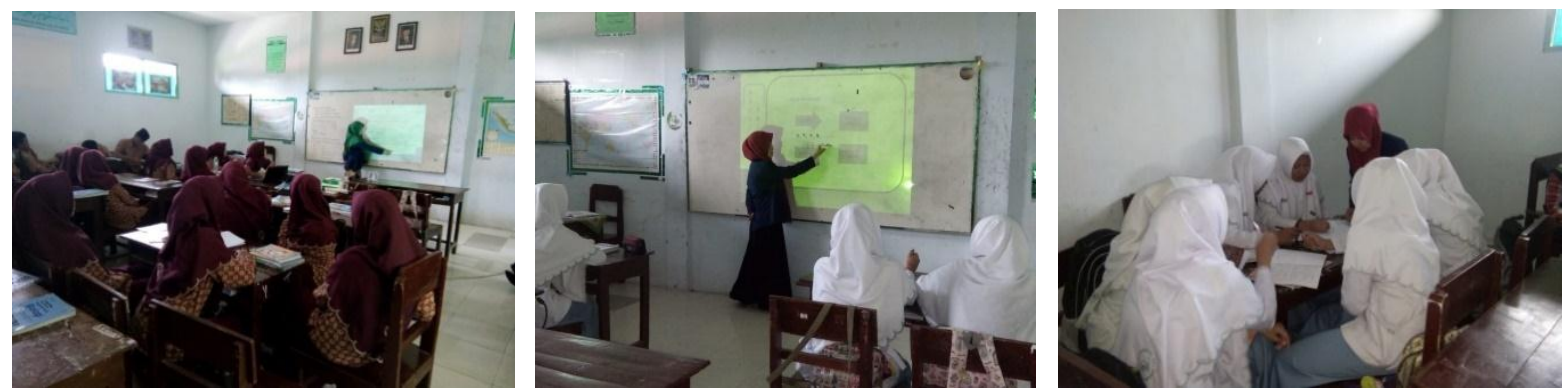

Gambar 1. Aktivitas Guru dalam Proses Pembelajaran

Pembelajaran dimulai dengan apersepsi yang diberikan guru dengan menanyakan kembali materi sebelumnya yaitu tentang pola bilangan genap dan ganjil. Berdasar pada gambar 1, guru menganalogikan pola bilangan genap dengan jumlah rakaat shalatdhuha (misalnya 2, 4, 6, 8, 10, 12) sedangkan pada pola bilangan ganjil, guru menganalogikannya 
dengan jumlah rakaat shalat witir (misalnya 1, 3, 5, 7, 9, dan 11). Kemudian guru memberikan LKS (Lembar Kerja Siswa) yang berisi tentang masalah kontekstual berbasis kehidupan Islami pondok pesantren yang berkaitan dengan barisan dan deret aritmetika. Guru berkeliling untuk mengarahkan dan membimbing siswa dalam menyelesaikan masalah tersebut.

\section{Tabel 1. Hasil Analisis Data Aktivitas Guru}

\begin{tabular}{|c|c|c|c|c|c|}
\hline \multirow{2}{*}{ No. } & \multirow{2}{*}{ Aspek yang Diamati } & \multicolumn{2}{|c|}{ Penilaian } & \multirow{3}{*}{ Rata-rata } & \multirow{3}{*}{ Kategori } \\
\hline & & RPP 1 & RPP 2 & & \\
\hline \multirow[t]{5}{*}{1.} & Pendahuluan: & & & & \\
\hline & $\begin{array}{l}\text { a. Kemampuan memotivasi siswa/ } \\
\text { mengomunikasikan } \\
\text { pembelajaran dan menjelaskan } \\
\text { tentang model } R M E \text {. }\end{array}$ & 4 & 4 & 4 & $\begin{array}{l}\text { Sangat } \\
\text { Baik }\end{array}$ \\
\hline & $\begin{array}{l}\text { b. Kemampuan menghubungkan } \\
\text { pelajaran saat itu dengan pelajaran } \\
\text { sebelumnya atau membahas PR. }\end{array}$ & 3 & 4 & 3,5 & $\begin{array}{l}\text { Sangat } \\
\text { Baik }\end{array}$ \\
\hline & $\begin{array}{l}\text { c. Kemampuan memimpin siswa dalam } \\
\text { pembentukan kelompok. }\end{array}$ & 4 & 4 & 4 & $\begin{array}{l}\text { Sangat } \\
\text { Baik }\end{array}$ \\
\hline & $\begin{array}{l}\text { d. Kemampuan guru menghubungkan } \\
\text { materi barisan dan deret aritmetika } \\
\text { dengan kehidupan Islami pondok } \\
\text { pesantren. }\end{array}$ & 4 & 4 & 4 & $\begin{array}{l}\text { Sangat } \\
\text { Baik }\end{array}$ \\
\hline \multirow[t]{10}{*}{2.} & Kegiatan Inti: & & & & \\
\hline & $\begin{array}{l}\text { a. Kemampuan menjelaskan } \\
\text { soal/masalah kontekstual. }\end{array}$ & 4 & 4 & 4 & $\begin{array}{l}\text { Sangat } \\
\text { Baik }\end{array}$ \\
\hline & $\begin{array}{l}\text { b. Kemampuan mengarahkan siswa } \\
\text { untuk menemukan jawaban dan cara } \\
\text { menjawab soal, dengan memberikan } \\
\text { bantuan terbatas. }\end{array}$ & 3 & 4 & 3,5 & $\begin{array}{l}\text { Sangat } \\
\text { Baik }\end{array}$ \\
\hline & $\begin{array}{l}\text { c. Kemampuan mengamati cara siswa } \\
\text { menyelesaikan soal/masalah. }\end{array}$ & 4 & 4 & 4 & $\begin{array}{l}\text { Sangat } \\
\text { Baik }\end{array}$ \\
\hline & $\begin{array}{l}\text { d. Kemampuan } \\
\text { interaksi siswa dalam bekerja. }\end{array}$ & 4 & 4 & 4 & $\begin{array}{c}\text { Sangat } \\
\text { Baik }\end{array}$ \\
\hline & $\begin{array}{l}\text { e. Kemampuan mendorong siswa untuk } \\
\text { membandingkan jawaban dengan } \\
\text { jawaban temannya (dengan anggota } \\
\text { kelompoknya). }\end{array}$ & 3 & 4 & 3,5 & $\begin{array}{l}\text { Sangat } \\
\text { Baik }\end{array}$ \\
\hline & $\begin{array}{l}\text { f. Kemampuan memimpin diskusi } \\
\text { kelas/menguasai kelas. }\end{array}$ & 4 & 4 & 4 & $\begin{array}{l}\text { Sangat } \\
\text { Baik }\end{array}$ \\
\hline & $\begin{array}{l}\text { g. Kemampuan menghargai berbagai } \\
\text { pendapat siswa. }\end{array}$ & 4 & 4 & 4 & $\begin{array}{l}\text { Sangat } \\
\text { Baik }\end{array}$ \\
\hline & $\begin{array}{l}\text { h. Kemampuan mengarahkan siswa } \\
\text { untuk menemukan sendiri dan } \\
\text { menarik kesimpulan tentang } \\
\text { konsep/prinsip/definisi/teorema/rumus } \\
\text { / prosedur matematika. }\end{array}$ & 3 & 3 & 3 & Baik \\
\hline & $\begin{array}{l}\text { i. Kemampuan mendorong siswa untuk } \\
\text { bertanya, mengeluarkan pendapat atau }\end{array}$ & 3 & 4 & 3,5 & $\begin{array}{l}\text { Sangat } \\
\text { Baik }\end{array}$ \\
\hline
\end{tabular}




\begin{tabular}{|c|c|c|c|c|c|}
\hline \multirow{3}{*}{ No. } & \multirow{2}{*}{ Aspek yang Diamati } & \multicolumn{2}{|c|}{ Penilaian } & \multirow{2}{*}{ Rata-rata } & \multirow{2}{*}{ Kategori } \\
\hline & & RPP 1 & RPP 2 & & \\
\hline & menjawab pertanyaan. & & & & \\
\hline \multirow[t]{3}{*}{3.} & Penutup: & & & & \\
\hline & $\begin{array}{l}\text { a. Kemampuan menegaskan hal-hal } \\
\text { penting/inti sari yang berkaitan } \\
\text { dengan pembelajaran. }\end{array}$ & 3 & 4 & 3,5 & $\begin{array}{l}\text { Sangat } \\
\text { Baik }\end{array}$ \\
\hline & $\begin{array}{l}\text { b. Kemampuan menyampaikan judul sub } \\
\text { materi berikutnya/memberika } \\
\text { PR/menutup pelajaran. }\end{array}$ & 4 & 4 & 4 & $\begin{array}{l}\text { Sangat } \\
\text { Baik }\end{array}$ \\
\hline 4. & Kemampuan Mengelola Waktu: & 4 & 4 & 4 & $\begin{array}{c}\text { Sangat } \\
\text { Baik }\end{array}$ \\
\hline \multirow[t]{3}{*}{5.} & Suasana Kelas: & & & & \\
\hline & a. Antusias Siswa & 4 & 4 & 4 & $\begin{array}{c}\text { Sangat } \\
\text { Baik }\end{array}$ \\
\hline & b. Antusias Guru & 4 & 4 & 4 & $\begin{array}{c}\text { Sangat } \\
\text { Baik }\end{array}$ \\
\hline
\end{tabular}
berikut:

Berdasarkan data pada Tabel 1, maka nilai aktivitas guru secara keseluruhan sebagai

$$
N A=\frac{\sum n}{\sum a}=\frac{68,5}{18}=3,805
$$

Berdasarkan kategori yang telah ditentukan, maka dapat disimpulkan bahwa aktivitas guru termasuk kategori sangat baik.

b. Aktivitas Siswa dalam Pembelajaran

Observasi terhadap aktivitas siswa dilakukan selama proses pembelajaran selama dua kali pertemuan. Berikut ini dokumentasi aktivitas siswa:
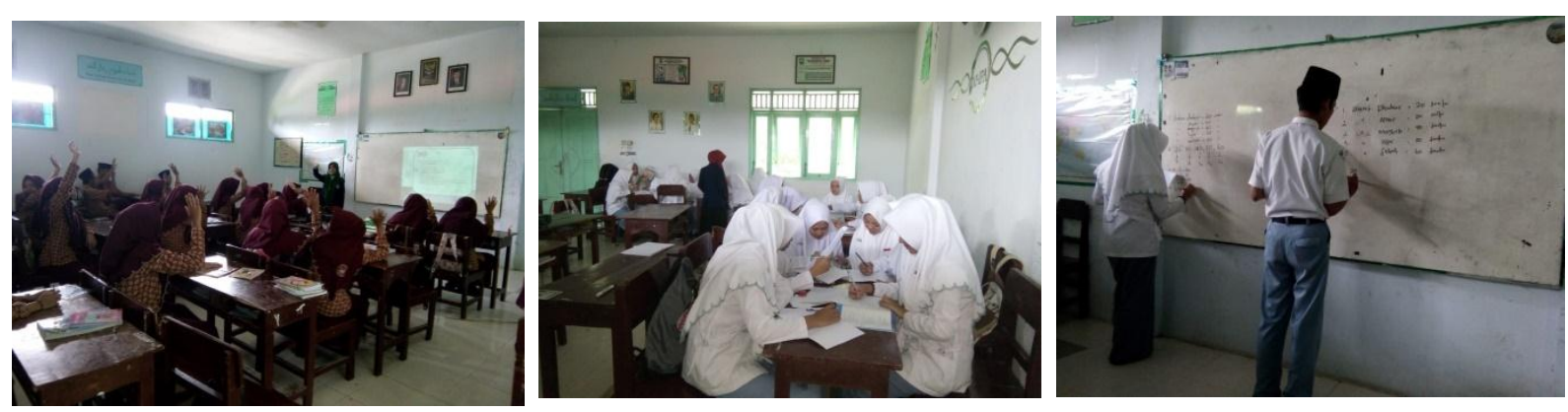

Gambar 2. Aktivitas Siswa dalam Proses Pembelajaran

Berdasar pada Gambar 2, terlihat bahwa selama proses pembelajaran siswa aktif bekerja sama dengan teman kelompoknya dalam menyelesaikan masalah yang diberikan. Mereka aktif bertanya tentang hal yang belum mereka pahami dengan senang hati guru membimbing mereka. Siswa juga bekerja sama dengan kelompoknya dalam menyelesaikan masalah kontekstual berbasis kehidupan Islami pondok pesantren. Selain itu, guru juga meminta siswa untuk mempresentasikan jawabannya dan kemudian guru membimbing siswa dalam diskusi kelas. Sebagian besar siswa sudah dapat menyelesaikan masalah dan dapat mengontruksi hasil pengerjaannya sehingga dapat menemukan konsep barisan dan 
deret aritmetika, meskipun ada salah satu kelompok yang belum menyelesaikan masalah sampai selesai serta dapat menyimpulkan hasil pengerjaannya.

Berdasar pada hasil observasi terhadap aktivitas siswa selama dua kali pertemuan maka nilai aktivitas siswa secara keseluruhan sebagai berikut:

$$
N A=\frac{\sum n}{\sum a}=\frac{16,7}{5}=3,34
$$

Berdasar pada kategori yang telah ditentukan, dapat disimpulkan bahwa aktivitas siswa termasuk kategori baik.

\section{c. Angket Respon Siswa}

Angket respon siswa diberikan kepada siswa setelah proses pembelajaran selesai. Berdasar pada hasil angket respon siswa, diperoleh persentase respon siswa terhadap pembelajaran RealisticMathematicEducation(RME) pada materi barisan dan deret aritmetika berbasis kehidupan Islami pondok pesantren adalah $98,5 \% \geq 60 \%$. Dari hasil tersebut, dapat disimpulkan bahwa siswa merespon "Positif" terhadap pembelajaran yang telah dilakukan.

\section{d. Tes Hasil Belajar Siswa}

Berdasar pada hasil dari tes belajar siswa dapat diketahui bahwa ketuntasan belajar individu terdapat 27 siswa yang tuntas dan 2 siswa yang tidak tuntas karena nilai yang diperoleh di bawah KKM. Sedangkan ketuntasan belajar klasikal dapat diketahui dengan menggunakan rumus sebagai berikut:

$$
K B K=\frac{\text { jumlah siswa yang tuntas }}{\text { jumlah seluruh siswa }} \times 100 \%=\frac{27}{29} \times 100 \%=93,1 \%
$$

$K B K=93,1 \geq 85 \%$. Hal ini menunjukkan bahwa siswa kelas XI IPA telah mencapai ketuntasan secara klasikal.

\section{PEMBAHASAN}

Proses pembelajaran yang dilakukan selama dua kali pertemuan pada akhirnya berjalan dengan lancar, meskipun ada beberapa siswa yang belum menyesuaikan dirinya dengan pembelajaran yang dilakukan oleh peneliti. Siswa belum terbiasa belajar dengan model RME yang berbasis kehidupan Islami pondok pesantren. Namun, dengan adanya bimbingan yang diberikan oleh guru, hal ini dapat diselesaikan dengan baik. Berdasar pada hasil observasi aktivitas guru dengan perolehan nilai akhir 3,805, maka guru dalam hal ini peneliti dapat dikatakan berhasil dalam menerapkan model RealisticMathematicEducation (RME) sesuai dengan langkah-langkah dan juga karakterisrik RME. Dalam hal ini guru bertindak sebagai fasilitator saja (Wubbels, 1997). Guru hanya memberikan arahan, bimbingan, dan bimbingan terbatas kepada siswa dalam menyelesaikan masalah tersebut.

Pembelajaran yang diterapkan oleh peneliti membuat aktivitas siswa aktif bertanya tentang hal yang belum mereka pahami. Mereka sangat antusias dalam mengikuti pembelajaran. Mereka juga sangat tertarik dengan pembelajaran yang diterapkan karena masalah kontekstual yang digunakan oleh peneliti berkaitan dengan kehidupan-kehidupan Islami yang sudah biasa dilakukan oleh siswa di pondok pesantren. Hal ini dapat ditunjukkan dengan hasil observasi aktivitas siswa dengan perolehan nilai akhir 3,34 (kategori BAIK). Hasil observasi aktivitas siswa ini sesuai dengan penelitian yang dilakukan oleh Saharah (2016) bahwa aktivitas siswa terhadap pembelajaran matematika dengan menggunakan model RME mengalami peningkatan. Selain itu, prinsip-prinsip, karakteristik, dan langkah-langkah RME dapat membuat pembelajaran menjadi menyenangkan (Revina, 2019). Oleh karena itu, sebagian besar siswa 
berpendapat bahwa pembelajaran yang diikuti mereka sangat menyenangkan sehingga dapat membuat mereka berminat dan semangat dalam belajar matematika

Pembelajaran dengan menggunakan model RME juga membuat siswa tertarik dan bersemangat karena mereka lebih mudah untuk memahami konsep barisan dan deret aritmetika. Hal ini berdasarkan dengan hasil angket yang menunjukkan bahwa siswa merespon "Positif" terhadap pembelajaran yang telah dilakukan selama dua kali pertemuan dengan perolehan persentase 98,5\%.Pengelolaan pembelajaran ini ternyata relevan dengan hasil tes belajar siswa yang dilakukan diakhir pembelajaran. Secara klasikal hasil tes belajar siswa memeroleh hasil 93,1\% sehingga ketuntasan belajar siswa secara klasikal dapat dikatakan "Tuntas". Hal ini sesuai dengan penelitian yang dilakukan oleh Ningsih (2013) bahwa 96\% siswa mampu menyelesaikan soal dan tidak mengalami kesulitan dalam menyelesaikannya.

Peneliti mencoba untuk menghubungkan matematika dengan kegiatan siswa yang sudah biasa dilakukan sehari-hari (Gravemeijer, 1995). Kegiatan tersebut merupakan kegiatan-kegiatan yang Islami, misalnya shalat witir dan shalatdhuha. Siswa sudah terbiasa melaksanakan ibadah sunnah tersebut karena merupakan suatu kegiatan rutin di pondok pesantren. Akan tetapi, mereka belum mengetahui tentang konsep matematika yang terdapat di dalamnya. Jumlah rakaat shalat witir sebanyak sebelas rakaat bisa dilakukan secara bertahap dengan hitungan ganjil (bisa 1 rakaat, 3, 5, 7, 9, dan 11 rakaat). Sedangkan jumlah rakaat shalatdhuha sebanyak dua belas rakaat bisa dilakukan secara bertahap dengan hitungan genap (bisa 2 rakaat, 4, 6, 8, 10, dan 12 rakaat). Hal ini sesuai dengan penelitian yang dilakukan oleh Jannah (2019) bahwa pengalaman dan pengetahuan awal siswa tentang konsep matematika memberikan aturan penting terhadap pemahaman siswa.

Pembelajaran matematika dengan model RME dapat membuat pembelajaran matematika lebih bermakna serta manfaatnya dapat dilihat dalam kehidupan nyata (Freudenthal, 1968). Oleh karena itu, peneliti menggunakan konteks yang Islami, misalnya shalat berjamaah, masjid, Pondok Pesantren, dan lain sebagainya. Hal ini sesuai dengan latar belakang sekolah MA Matsaratul Huda yang berbasis pondok pesantren. Menurut Cooper (2002) untuk mendorong siswa dalam mengaplikasikan matematika adalah dengan memberikan masalah kontekstual dalam pembelajaran matematika berdasar pada kehidupan sehari-hari sehingga dapat meningkatkan permeabilitas batas antara pengetahuan dan pengalaman sehari-hari siswa. Oleh karena itu, peneliti mencoba untuk menggunakan kegiatan-kegiatan siswa yang biasa dilakukan dalam kehidupan sehari-hari mereka sehingga mereka tertarik untuk mempelajari matematika dan lebih mudah dalam menyelesaikan masalah matematika. Hal ini ditunjukkan dengan aktivitas siswa selama pembelajaran. Mereka aktif bertanya, menjawab, dan menyampaikan pendapat. Selain itu, sebagian besar siswa mengalami ketuntasan individu dalam menyelesaikan tes hasil belajar.

\section{SIMPULAN}

Penelitian ini dapat disimpulkan bahwa penerapan model RealisticMathematicEducation(RME) pada materi barisan dan deret aritmetika berbasis kehidupan Islami di lingkunagan pondok pesantren di kelas XI IPA Matsaratul Huda Panempan Pamekasan dapat berjalan dengan lancar. Hal ini dapat ditunjukkan dengan hasil observasi aktivitas guru dengan nilai akhir 3,805. Sedangkan hasil observasi aktivitas siswa memperoleh nilai akhir 3,34. Selain itu, siswa juga merespon "Positif" terhadap pembelajaran yang telah dilakukan selama dua kali pertemuan dengan perolehan persentase 98,5\%. Pengelolaan pembelajaran ini ternyata relevan dengan hasil tes belajar siswa yang dilakukan di akhir pembelajaran. Secara klasikal hasil tes belajar siswa memperoleh hasil 93,1\% sehingga ketuntasan belajar siswa secara klasikal dapat dikatakan "Tuntas". Sedangkan secara individu 
terdapat 27 siswa yang tuntas dan 2 siswa yang tidak tuntas karena nilai yang diperoleh berada dibawah KKM.

Penelitian ini diharapkan dapat dijadikan acuan bagi guru matematika dalam memberikan pembelajaran yang lebih baik. Selain itu, untuk meningkatkan prestasi belajar peserta didik, guru hendaknya berupaya mengenal lebih jauh karakteristik materi serta para peserta didiknya, sehingga bisa secara selektif memilih model pembelajaran yang tepat sehingga berdampak pada terciptanya suasana proses pembelajaran yang kondusif, para peserta didik lebih aktif, serta didapat desain pembelajaran yang menyenangkan.

\section{UCAPAN TERIMA KASIH}

Terima kasih kepada beberapa pihak atas dukungan khususnya Prodi Pendidikan Matematika Universitas Madura dan MA Matsaratul Huda Panempan Pamekasan.

\section{DAFTAR RUJUKAN}

Arikunto, S. (2016). Prosedur Penelitian Suatu Praktik. Jakarta: PT. RINEKA CIPTA

Cooper, B. \&Harries, T. (2002). Children'sResponsestoContrasting 'Realistic' MathematicsProblems: JustHowRealistic are Children Ready to Be. Educational Studies in Mathematics, 49(2), 1-23 https://www.jstor.org/action/doBasicSearch?Query

Creswell, J. W. (2013). Qualitative, Quantitative, andMixedMethodApproachesThirdEdition. California: SAGE Publication

Fathani, A. H. (2014). Matematika Hakikat dan Logika. Yogyakarta: Ar-Ruzz Media

Freudenthal, H. (1968). WhytoTeachMathematicsSo As tobeUseful.EducationalStudies in Mathematics, 1(1-2). 3-8 https://link.springer.com/article/10.1007/BF00426224

Gravemeijer, K. P. E. (1995). DevelopingrealisticMathematicsEducation (Ontwikkelenvanrealistisch reken/wiskundeonderwijs). TijdschriftvoorDidactiekder $B$ wetenschappen, 13(3), 271-276 https://research.vu.nl/en/publications

Gravemeijer, K. \&Doorman, M. (1999). ContextProblems in RealisticMathematicsEducation: A CalculusCourse As An Example.Educational Studies in Mathematics, 39(1-3), 111-129 https://link.springer.com/article/10.1023/A\%3A1003749919816

Jannah, U. R. (2013). Teori Dienes dalam Pembelajaran Matematika. Jurnal Interaksi, 8(2), 126-131Error!

Hyperlink reference

not valid.http://ejournal.unira.ac.id/index.php/jurnal_interaksi/article/viewFile/324/274

Jannah, U. R., Nusantara,T., Sudirman. \& Sisworo. (2019). Students' CharacteristicsofStudents' Obstacles in Understanding The Definitionof A fuction. IOP Conf. Ser. EarthEnviron. Sci, 243(012134)

La Jamaa. (2015). Integrasi Matematika dan Islam. (Online), accessed 09 November 2018, 1-6 https://syariah.iainambon.ac.id/index.php/artikel-dosen/integrasimatematikadan-islamdr-la-jamaamhi

Moleong, L. J. (2013). Metode Peneltian Kualitatif. Bandung: PT Remaja Rosdakarya

Ningsih, P. R. (2013). Penerapan Metode RealisticMathematicEducation (RME) pada Pokok Bahasan Perbandingan Senilai dan Berbalik Nilai di Kelas VII E SMP IPIEMS Surabaya. Gamatika, $3(2)$,

$177-184$ https://www.journal.unipdu.ac.id/index.php/gamatika/article/view/377

Papadakis, S., Kalogiannakis, M. \&Zaranis, N. (2017). ImprovingMathematicsTeaching in KindergartenwithRealisticMathematicalEducation. Early ChildhoodEducationJournal 45(3), 369-378 https://link.springer.com/article/10.1007/s10643-015-0768-4

Revina, S. \&Leung, F. K. S. (2019). HowtheSameFlowersGrow in DifferentSoils? The ImplementationofRealisticMathematicsEducation in Utrechtand Jakarta Classrooms. 
International JournalofScienceandMathematicsEducation, $\quad 17(3), \quad$ 565-589 https://link.springer.com/article/10.1007/s10763-018-9883-1

Saharah., I Nyoman, M. \& Baharuddin, P. (2016). Penerapan Pendekatan Matematika Realistik untuk Meningkatkan Hasil Belajar Siswa Kelas 1 SD Integral Rahmatullah Tolitoli pada Materi Penjumlahandan Pengurangan Bilangan. Jurnal Kreatif Tadulako, 4(3),178-192 http://jurnal.untad.ac.id/jurnal/index.php/JKTO/article/view/5484

Subaidi, A. (2016). Penerapan Pendekatan ContextualTeachingandLearning (CTL) dengan SettingLearningTogether (LT) pada Pokok Bahasan Bangun Ruang Sisi Datar. Sigma, 2(1), 1-4 http://ejournal.unira.ac.id/index.php/jurnal_sigma/article/view/69/54

Van Den Heuvel-Panhuizen, M. (2003). The Didactical Use ofModels in RealisticMathematicsEducation: An Examplefrom A Longitudinal Trajectory On Percentage. Educationalstudies in Mathematics, 54(1), 9-35 https://link.springer.com/article/10.1023/B\%3AEDUC.0000005212.03219.dc

Wijaya, A. (2012). Pendidikan Matematika Realistik: Suatu Alternstif Pendekatan Pembelajaran Matematika. Yogyakarta: Graha Ilmu

Wubbels, T., Korthagen, F. \& Broekman, H. (1997). Preparing Teachers for Realistic Mathematics Education, Educational Studies in Mathematics, 32(1), 1-28 https://link.springer.com/article/10.1023/A:1002900522457

Zulkardi, Z., Putri, R. I. I. \& Wijaya, A. (2019). In M. vandenHeuvel-Panhuizen (Ed.), VisionsonandExperienceswithRealisticMathematicsEducation.

International

ReflectionsontheNetherlandsDidacticsofMathematics 